Article

\title{
Nutrient Removal Efficiency and Growth of Watercress (Nasturtium officinale) under Different Harvesting Regimes in Integrated Recirculating Aquaponic Systems for Rearing Common Carp (Cyprinus carpio L.)
}

\author{
Tareq Irhayyim ${ }^{1, *} \mathbb{0}$, Milán Fehér ${ }^{2, *}$, Judit Lelesz ${ }^{2}$, Miklós Bercsényi $^{1}$ and Péter Bársony ${ }^{2}$ \\ 1 Georgikon Fish Research Laboratory, Georgikon Faculty, University of Pannonia, H-8360 Keszthely, \\ Hungary; bm@georgikon.hu \\ 2 Laboratory of Aquaculture, Institute of Animal Science, Biotechnology and Nature Conservation, \\ Department of Animal Husbandry, University of Debrecen, H-4032 Debrecen, Hungary; \\ lelesz.judit@agr.unideb.hu (J.L.); barsonp@agr.unideb.hu (P.B.) \\ * Correspondence: tareq.irhayyim.saad.sulaimawi@2018.georgikon.hu (T.I.); feherm@agr.unideb.hu (M.F.)
}

Received: 25 April 2020; Accepted: 14 May 2020; Published: 16 May 2020

\begin{abstract}
The harvesting of plant biomass is usually implemented as an effective tool for plant management and removing the nutrients absorbed in plant tissues. Here, the influence of harvesting different biomasses $(50 \%, 33 \%, 25 \%$, and $0 \%$ (no harvest)) of watercress (Nasturtium officinale) was investigated in integrated recirculating aquaponic systems (IRASs) for rearing common carp (Cyprinus carpio). Twelve independent IRASs were designed $(4 \times 3)$; each system consisted of a fish rearing tank, a waste collection tank, and a hydroponic bed. Water quality parameters and the growth of both fish and plants were measured in all the systems, and then the nutrient removal capacities of the hydroponic beds were calculated. The results revealed that increasing the biweekly harvested biomass of the plants decreased the growth of the watercress, while it did not affect the growth of the common carp. Increasing the harvested biomass of the plants also decreased the nitrate nitrogen and orthophosphate removal efficiencies of the aquaponic systems, while it did not affect the ammonia and nitrite nitrogen removal efficiencies. Therefore, a biweekly harvesting of less than $25 \%$ of the biomass of the growing watercress is recommended for efficient nutrient removal and the sustainable growth of both watercress and the common carp in aquaponic systems.
\end{abstract}

Keywords: biomass harvesting; common carp; integrated recirculating aquaponic system; nutrients removal; watercress

\section{Introduction}

Aquaponic systems are the integrated recirculating aquaculture systems (IRASs) that combine aquaculture and hydroponics [1,2]. These systems are gaining popularity because they offer many advantages in terms of reducing water consumption, increasing the profitability of primary and secondary products, recycling nutrients, and reducing the environmental impacts of aquaculture $[3,4]$. Aquaponics is a symbiotic production system between fish, microbes, and plants. After fish digest food, ammonia nitrogen is excreted into the water, and high levels of ammonia can negatively affect fish growth and survival. Nitrifying bacteria can utilise ammonia nitrogen and convert it into nitrite and then to nitrate. Finally, plants can absorb and utilise nitrate for growth [3].

Among the most economical plant species that can grow in the aquaponic systems are leafy greens such as basil, spinach, chives, mint, and watercress [5]. Watercress (Nasturtium officinale) is an aquatic, 
perennial herb consumed by humans as a salad green and medicinal herb. The plant has relatively large quantities of beta carotene (vitamin A), ascorbic acid (vitamin C), folic acid, iron, iodine, calcium, and phosphorous. It also contains a high level of amino acids (arginine, glycine, lysine and tryptophan) and antioxidants [6]. Watercress is in high demand and has a high economic value in urban areas, which makes it a very suitable crop for commercial or small scale farming. The demand for watercress is greater than the amount that business can supply to the market [5].

The common carp (Cyprinus carpio L.) was also chosen as a model species in the current study because it has a wide distribution throughout the world and can survive in poor water quality. The majority of carp production in Central and Eastern Europe comes from extensive and semi-intensive fishpond operations, where untreated pond water discharged into the environment causes environmental problems [7]. In response to the increasingly strict environmental regulations in the region, improving carp farming practices and reducing their environmental impact would be a new desirable trend for ecological approaches and sustainability.

In aquaponic systems, three strategies have been adopted for producing crops: staggered cropping, intercropping, and batch cropping [1]. A staggered production system is one where a group of plants are harvested at different stages of growth. This allows the crop to be harvested repeatedly and keeps the nutrient uptake in the culture system relatively constant. This system is most effective for crops that can be grown continuously such as leafy green vegetables and herbs [1]. However, if the harvesting of the plants is too much, the number of plants in the bed will reduce and the uptake of the nutrients in the aquaponic system may decrease, resulting in nutrient accumulation and, eventually, fish mortality. Therefore, the selection of the appropriate biomass of plants to be harvested can optimise nutrient uptake efficiency and sustain plant development in aquaponic systems.

Additionally, several studies have suggested that overall nutrient removal could be improved if a harvesting regime is applied [8-10], but others reveal that harvesting can negatively affect nutrient removal [11-13]. The importance of harvest management for the nutrient removal, as well as the growth and development of plants, has always been highly controversial [8,13-16]. Despite the idea of nutrient reduction through harvesting having gained more attention over the last decade [17], little published information is available on the requirement of the optimum harvesting of the biomass of plants in integrated recirculating aquaponic systems. Therefore, this study aimed to investigate the effects of harvesting different biomasses of watercress on water quality, nutrient removal efficiency, and the growth of both watercress and the common carp in an integrated recirculating aquaponic system.

\section{Materials and Methods}

\subsection{Experimental Fish and Plants}

A total number of 144 common carp (C. carpio L.) with an average weight of $33.67 \pm 0.012 \mathrm{~g}$ were used for the experiment. Fish were collected from a stock tank at the Aquaculture Laboratory of Debrecen University (ALDU), Hungary. Watercress (N. officinale) was also taken from a growing hydroponic bed in an operating aquaponic system at ALDU. Healthy seedlings (144 seedlings) that already had white roots with an average height of $6 \mathrm{~cm}$ and a weight of $20 \mathrm{~g}$ were transplanted into 12 hydroponic units. Each hydroponic unit was stocked with twelve seedlings of watercress.

\subsection{Design of Systems}

The trial comprised 12 independent experimental systems; each system consisted of a $200 \mathrm{~L}$ fish tank, a $20 \mathrm{~L}$ waste collection tank, and a $0.086 \mathrm{~m}^{3}$ hydroponic unit with expanded clay. The fish and waste collection tanks were placed on the floor, while the hydroponic unit was installed on a plastic stand to elevate it above the fish tank. Water from the waste collection tank was pumped through a plastic tube at a flow rate of $3 \mathrm{~L} / \mathrm{min}$ to the hydroponic unit by a submerged pump. Water from the hydroponic unit was circulated to the fish tank and then returned back through a PVC pipe to the waste collection tank by gravity (Figure 1). The outlet of each hydroponic unit was constructed as 
a bell siphon with a maximum water level of $15 \mathrm{~cm}$ and an auto-mechanical water out movement, initiating the ebb under water pressure. The water volumes in the fish and waste collection tanks were maintained at $100 \mathrm{~L}$, and $17 \mathrm{~L}$, respectively. The fish tank was supplied with one air stone to provide dissolved oxygen for the fish, and a polyethylene mesh was put above the fish tank to prevent the fish from jumping outside. All the experimental systems were operated with fish and plants for four days before the commencement of the experiment to acclimate the fish and plants to the experimental systems.

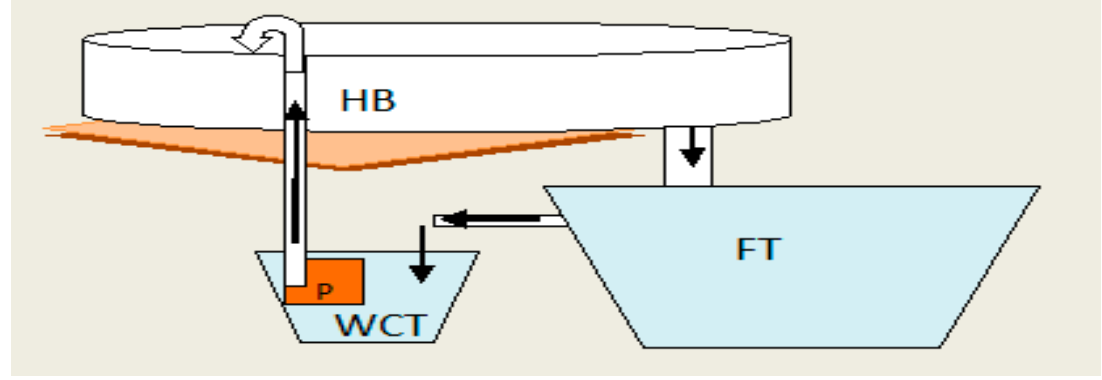

Figure 1. Diagram of the experimental units (the arrows show the direction of water flow); FT: Fish tank; WCT: Waste collection tank; HB: Hydroponic bed; P: Pump.

\subsection{Experimental Setup and Rearing Conditions}

The trial was conducted for 58 days in an insulated greenhouse at ALDU, and only natural light was used to provide uniform conditions for fish and plant growth. Initially, 12 seedlings of plants with a total biomass of $240 \mathrm{~g}$ were transplanted into each hydroponic unit $\left(0.43 \mathrm{~m}^{2}\right.$ surface area $)$. The effect of harvesting different biomass ratios of above-ground plants was evaluated by a random design with three replicates. There were four treatments: harvesting $0 \%, 25 \%, 33 \%$, and $50 \%$ of plants biweekly from the surface area of each hydroponic bed. Harvesting was carried out in such a way that the five centimetre above-ground portion of the plants remained in place to allow the plants to regrow again. The fish were initially stocked at $2.02 \mathrm{~kg} / \mathrm{m}^{3}$, and the total biomass was approximately $404 \mathrm{~g} /$ tank. The feeding rate for the fish was $2 \%$ of body weight per day, and all the fish were fed by hand twice a day at 09:00 and 15:00 hours with the commercially formulated feed (pellet size $2 \mathrm{~mm}$ ) Aller Master (35\% crude protein, 9\% crude fat, 4.7\% crude fibre, 7\% crude ash, and 1.1\% P) (Aller Aqua Group, Allervej, Christiansfeld, Denmark). The uneaten feed and faeces were siphoned out daily before feeding and separated from the siphoned water by a $100 \mu \mathrm{m}$ mesh size net, and then the water was returned back into the fish tank of the same system. Depending on the loss of technological water, the necessary amount of new water was added ( 20-30 L) every ten days (including the water to compensate that lost by evaporation).

\subsection{Water Quality Parameters}

The dissolved oxygen (DO), temperature, and $\mathrm{pH}$ were measured in the fish tanks and hydroponic beds once a day before feeding using a Hach HQ30d portable meter (HACH CO., Loveland, Colorado, USA). Triplicate water samples were collected every 10 days from the fish tanks, as were the influent and effluent waters of each hydroponic unit to determine the nutrient removal rates. Ammonia nitrogen $\left(\mathrm{NH}_{3}-\mathrm{N}\right)$, nitrite nitrogen $\left(\mathrm{NO}_{2}-\mathrm{N}\right)$, nitrate nitrogen $\left(\mathrm{NO}_{3}-\mathrm{N}\right)$, orthophosphate $\left(\mathrm{PO}_{4}-\mathrm{P}\right)$, and total phosphorus (TP) were measured with the HACH Lange DR/3900 spectrophotometer (HACH CO., Loveland, Colorado, USA), using spectrophotometric methods outlined by the HACH company. The levels of $\mathrm{NH}_{3}-\mathrm{N}, \mathrm{NO}_{2}-\mathrm{N}$, and $\mathrm{NO}_{3}-\mathrm{N}$ were determined using the Nessler method (Method 8038), diazotisation method (Method 8507), and cadmium reduction method (Method 8039), respectively [18]. The TP and $\mathrm{PO}_{4}-\mathrm{P}$ were determined by the phosphor-molybdenum blue method (HACH, Lange, 
LCK349, Phosphate Ortho/Total cuvette test), according to the ISO 6878_2004, DIN EN 6878/D11 standard [18].

The nutrient removal rates (NRR) were used to determine the nutrient removal cycle in each system. The nutrient removal rate (NRR\%) was calculated using the following equation [19]:

$$
\mathrm{NRR} \%=\left[\left(\mathrm{C}_{\mathrm{I}}-\mathrm{C}_{\mathrm{E}}\right) / \mathrm{C}_{\mathrm{I}}\right] \times 100
$$

where $C_{I}$ and $C_{E}$ are the concentrations of a particular nutrient in the influent and effluent waters of the grow beds, respectively.

\subsection{Fish and Plant Growth Parameters}

The growth and survival rates of the fish were recorded at the end of the experiment for each tank. The specific growth rates (SGR), fish weight gain (WG), feed conversion ratio (FCR), and survival rates were calculated using the following formulas:

$$
\begin{gathered}
\text { SGR }(\% / \text { day })=100 \times(\ln W t-\ln W 0), \\
W G=W t-W 0, \\
F C R=W F(g) / W G(g), \\
\text { Survival rate }(\%)=100 \times(\mathrm{nt} / \mathrm{n} 0),
\end{gathered}
$$

where Wt and W0 are the weights of fish at the end and the start of the trial, respectively, and ( $t)$ is the number of rearing days. The WF is the weight of feed given to the fish (g), and WG is the weight gain of the fish (g). The nt and $n 0$ are the numbers of fish at the end and the start of the trial, respectively.

At the end of the experiment, all the plants were harvested from the hydroponic beds and the weight of the plants was recorded. The final biomass (FB), biomass gain, and specific growth rates of plants (SGRP) were calculated using the following equations:

Final biomass production of plants $(\mathrm{FB})=$ Cumulative amount of plants harvested during the harvestings throughout the trial $(\mathrm{g})$,

$$
\begin{aligned}
& \text { Biomass gain of plants }(\mathrm{g})=\mathrm{FB}-\mathrm{IB}, \\
& \operatorname{SGRP}(\% / \text { day })=100 \times(\operatorname{lnFB}-\operatorname{lnIB}) / \mathrm{t},
\end{aligned}
$$

where FB and IB are the final biomass of the plants and the initial stocked biomass, respectively, while $t$ is the number of rearing days.

\subsection{Statistical Analysis}

All statistical analyses were performed using SPSS version 22.0 for windows. All the data obtained were tested for normality of distribution and homogeneity of variance. One-way analysis of variance (ANOVA) was conducted to test the differences between the parameters amongst treatments. Significant ANOVAs were followed by Duncan's multiple range tests to recognise specific differences amongst treatments. A $p<0.05$ was considered significant for all analyses.

\section{Results}

\subsection{Water Quality Parameters in Fish Tanks}

The means for all the water quality parameters in the fish tanks were similar $(p>0.05)$ amongst the treatments except for $\mathrm{PO}_{4}-\mathrm{P}$ and TP (Table 1). The lowest means for $\mathrm{PO}_{4}-\mathrm{P}$ and TP were recorded in the fish tanks of the unharvested systems $(0 \%)$, which significantly differed $(p<0.05)$ from those of the other three treatments (Table 1). The dissolved oxygen in all the treatments never dropped below 
$7 \mathrm{mg} / \mathrm{L}$, whereas the temperature decreased as the trial progressed from $16.7^{\circ} \mathrm{C}$ to $11.5^{\circ} \mathrm{C}$. The mean $\mathrm{pH}$ values fluctuated in all the treatments between 7.01 and 7.65. The mean $\mathrm{NH}_{3}-\mathrm{N}$ concentrations decreased in all the treatments as the trial progressed, while the mean $\mathrm{NO}_{2}-\mathrm{N}$ concentrations fluctuated over time (Figure 2a,c). The means for $\mathrm{NO}_{3}-\mathrm{N}$ increased in all the treatments during the first 30 days and decreased after that, with the highest means in the $33 \%$ and $50 \%$ harvested systems (Figure $2 \mathrm{~d}$ ). The mean $\mathrm{PO}_{4}-\mathrm{P}$ and TP concentrations for all the treatments decreased as the trial progressed, and the highest means were recorded at the early stage of the culture period (Figure 2e,f).
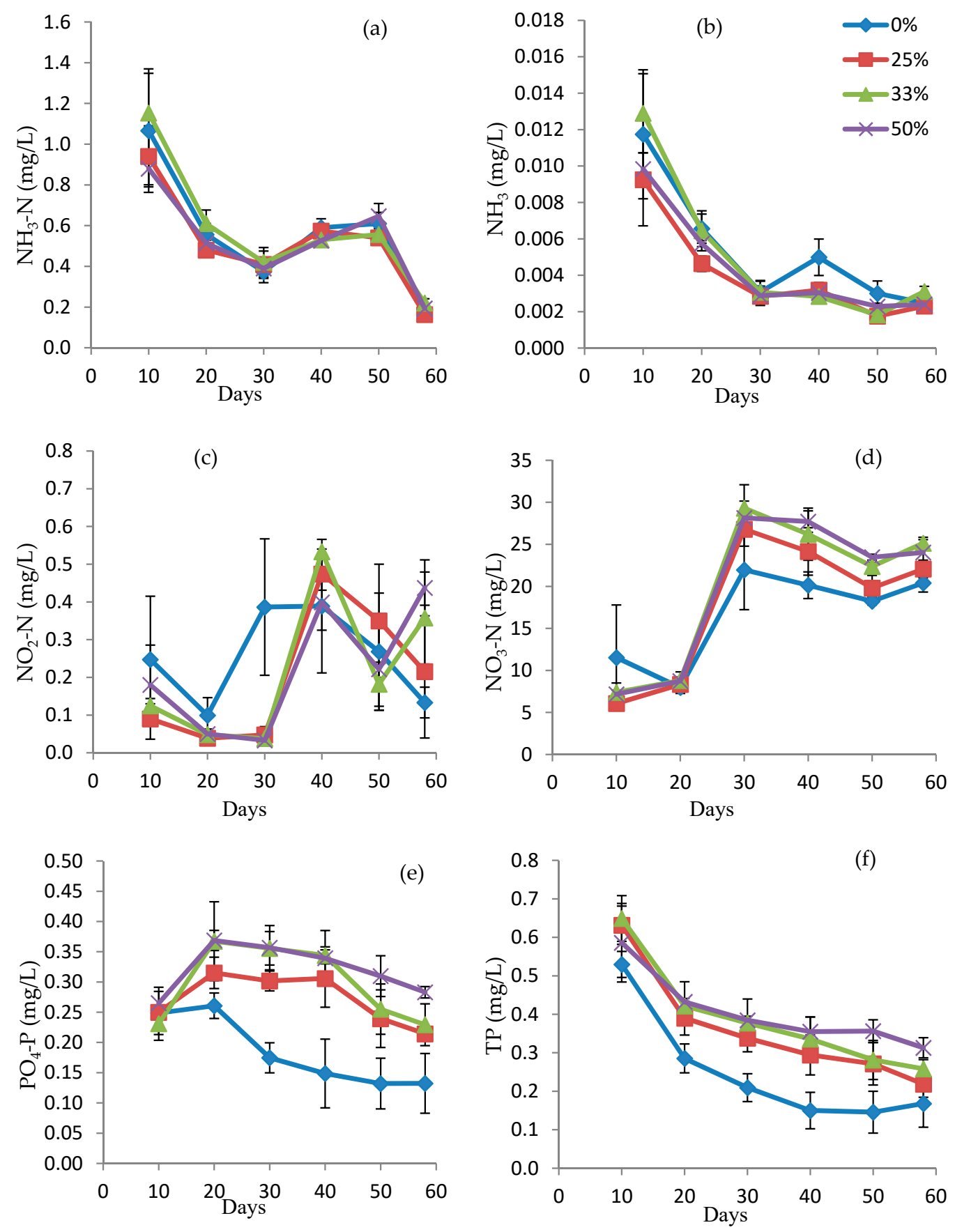

Figure 2. Concentrations of (a) ammonia nitrogen; (b) un-ionised ammonia; (c) nitrite nitrogen; (d) nitrate nitrogen; (e) orthophosphate; and (f) total phosphorus (TP) in tanks of Cyprinus carpio reared in an integrated recirculating aquaponic system for a 58 day trial (data are the means of three replicates $(\mathrm{n}=3)$, and error bars indicate the standard errors). 
Table 1. Overall mean water quality parameters in the fish tanks and hydroponic units of aquaponic systems under different plant harvesting regimes.

\begin{tabular}{|c|c|c|c|c|}
\hline \multirow{2}{*}{ Water Parameters } & \multicolumn{4}{|c|}{ Harvested Biomass } \\
\hline & $0 \%$ & $25 \%$ & $33 \%$ & $50 \%$ \\
\hline \multicolumn{5}{|l|}{ Fish Tanks } \\
\hline $\mathrm{NH}_{3}-\mathrm{N}(\mathrm{mg} / \mathrm{L})$ & $0.56 \pm 0.08^{a}$ & $0.52 \pm 0.06^{a}$ & $0.58 \pm 0.07^{a}$ & $0.53 \pm 0.05^{a}$ \\
\hline $\mathrm{NH}_{3}(\mathrm{mg} / \mathrm{L})$ & $0.005 \pm 0.001^{\mathrm{a}}$ & $0.004 \pm 0.001^{\mathrm{a}}$ & $0.005 \pm 0.001^{\mathrm{a}}$ & $0.004 \pm 0.001^{\mathrm{a}}$ \\
\hline $\mathrm{NO}_{2}-\mathrm{N}(\mathrm{mg} / \mathrm{L})$ & $0.25 \pm 0.05^{\mathrm{a}}$ & $0.20 \pm 0.05^{\mathrm{a}}$ & $0.21 \pm 0.04^{\mathrm{a}}$ & $0.22 \pm 0.04^{\mathrm{a}}$ \\
\hline $\mathrm{NO}_{3}-\mathrm{N}(\mathrm{mg} / \mathrm{L})$ & $16.71 \pm 1.68^{\mathrm{a}}$ & $17.87 \pm 3.1 .98^{\mathrm{a}}$ & $19.86 \pm 2.17^{\mathrm{a}}$ & $19.87 \pm 2.12^{\mathrm{a}}$ \\
\hline $\mathrm{PO}_{4}-\mathrm{P}(\mathrm{mg} / \mathrm{L})$ & $0.18 \pm 0.02^{b}$ & $0.27 \pm 0.01^{\mathrm{a}}$ & $0.29 \pm 0.02^{\mathrm{a}}$ & $0.32 \pm 0.01^{\mathrm{a}}$ \\
\hline $\mathrm{TP}(\mathrm{mg} / \mathrm{L})$ & $0.25 \pm 0.04^{b}$ & $0.36 \pm 0.04^{\mathrm{a}}$ & $0.39 \pm 0.03^{\mathrm{a}}$ & $0.40 \pm 0.03^{\mathrm{a}}$ \\
\hline Dissolved oxygen $(\mathrm{mg} / \mathrm{L})$ & $8.16 \pm 0.07^{\mathrm{a}}$ & $8.19 \pm 0.06^{\mathrm{a}}$ & $8.24 \pm 0.06^{\mathrm{a}}$ & $8.34 \pm 0.06^{\mathrm{a}}$ \\
\hline $\mathrm{pH}$ & $7.41 \pm 0.02^{\mathrm{a}}$ & $7.35 \pm 0.04^{\mathrm{a}}$ & $7.37 \pm 0.03^{a}$ & $7.40 \pm 0.04^{\mathrm{a}}$ \\
\hline Temperature $\left({ }^{\circ} \mathrm{C}\right)$ & $14.71 \pm 0.35^{\mathrm{a}}$ & $14.45 \pm 0.34^{\mathrm{a}}$ & $14.29 \pm 0.33^{a}$ & $14.21 \pm 0.33^{a}$ \\
\hline \multicolumn{5}{|l|}{ Bed Units } \\
\hline Dissolved oxygen $(\mathrm{mg} / \mathrm{L})$ & $8.16 \pm 0.07^{a}$ & $8.15 \pm 0.07^{a}$ & $8.22 \pm 0.07^{a}$ & $8.20 \pm 0.08^{a}$ \\
\hline $\mathrm{pH}$ & $7.41 \pm 0.03^{a}$ & $7.38 \pm 0.04^{\mathrm{a}}$ & $7.37 \pm 0.04^{\mathrm{a}}$ & $7.40 \pm 0.04^{\mathrm{a}}$ \\
\hline Temperature $\left({ }^{\circ} \mathrm{C}\right)$ & $14.44 \pm 0.34^{\mathrm{a}}$ & $14.37 \pm 0.34^{\mathrm{a}}$ & $14.26 \pm 0.33^{\mathrm{a}}$ & $14.16 \pm 0.33^{a}$ \\
\hline
\end{tabular}

Values (means \pm SE) in the same row with different superscript letters $(a, b \ldots$ ) are significantly different (Duncan test; $p<0.05)$; data are the means of three replicates $(\mathrm{n}=3)$.

\subsection{Nutrient Removal Rates}

There were no significant differences $(p>0.05)$ in the mean removal rates for $\mathrm{NH}_{3}-\mathrm{N}$ and $\mathrm{NO}_{2}-\mathrm{N}$ amongst any of the treatments (Table 2). The mean $\mathrm{NH}_{3}-\mathrm{N}$ and $\mathrm{NO}_{2}-\mathrm{N}$ removal rates increased in all the treatments over time (Figure $3 a, b$ ). The highest removal rates for $\mathrm{NO}_{3}-\mathrm{N}, \mathrm{PO}_{4}-\mathrm{P}$, and TP were calculated in the unharvested system, which significantly differed $(p<0.05)$ from those in the 33\% and $50 \%$ systems (Table 2). However, the mean $\mathrm{NO}_{3}-\mathrm{N}, \mathrm{PO}_{4}-\mathrm{P}$, and $\mathrm{TP}$ removal rates in the $25 \%$ harvested systems were comparable with those in the unharvested and $33 \%$ harvested systems (Table 2). The mean $\mathrm{NO}_{3}-\mathrm{N}$ removal rates in the unharvested systems increased over time, while the means for the other three treatments slightly decreased at the later stage of the culture period (Figure 3c). The mean $\mathrm{PO}_{4}-\mathrm{P}$ and TP removal rates increased in all treatments over time (Figure 3d,e).

Table 2. Overall mean nutrient removal efficiency for each treatment during the 58 day trial.

\begin{tabular}{ccccc}
\hline \multirow{2}{*}{ Removal Rates } & \multicolumn{4}{c}{ Harvested Biomass } \\
\cline { 2 - 5 } & $\mathbf{0 \%}$ & $\mathbf{2 5 \%}$ & $\mathbf{3 3 \%}$ & $\mathbf{5 0 \%}$ \\
\hline $\mathrm{NH}_{3}-\mathrm{N}(\%)$ & $36.20 \pm 3.19^{\mathrm{a}}$ & $35.06 \pm 3.82^{\mathrm{a}}$ & $31.80 \pm 2.74^{\mathrm{a}}$ & $31.88 \pm 2.93^{\mathrm{a}}$ \\
$\mathrm{NO}_{2}-\mathrm{N}(\%)$ & $42.43 \pm 3.24^{\mathrm{a}}$ & $41.67 \pm 3.96^{\mathrm{a}}$ & $47.14 \pm 3.10^{\mathrm{a}}$ & $42.58 \pm 4.23^{\mathrm{a}}$ \\
$\mathrm{NO}_{3}-\mathrm{N}(\%)$ & $63.58 \pm 2.36^{\mathrm{a}}$ & $59.67 \pm 2.78^{\mathrm{ab}}$ & $54.26 \pm 2.33^{\mathrm{bc}}$ & $49.49 \pm 2.78^{\mathrm{c}}$ \\
$\mathrm{PO}_{4}-\mathrm{P}(\%)$ & $31.09 \pm 1.19^{\mathrm{a}}$ & $28.44 \pm 0.94^{\mathrm{ab}}$ & $26.33 \pm 1.34^{\mathrm{bc}}$ & $24.97 \pm 1.13^{\mathrm{c}}$ \\
$\mathrm{TP}(\%)$ & $47.31 \pm 1.25^{\mathrm{a}}$ & $46.56 \pm 0.93^{\mathrm{ab}}$ & $44.76 \pm 0.83^{\mathrm{b}}$ & $43.06 \pm 1.17^{\mathrm{b}}$ \\
\hline
\end{tabular}

Values (means \pm SE) in the same row having different superscript letters $(a, b, c \ldots$ ) are significantly different (Duncan test; $p<0.05)$; data are the means of three replicates $(\mathrm{n}=3)$. 


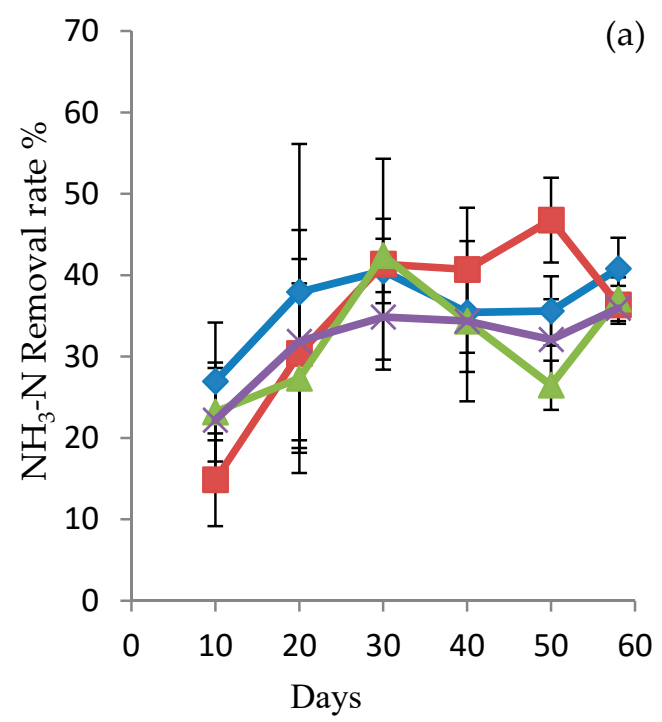

(b)
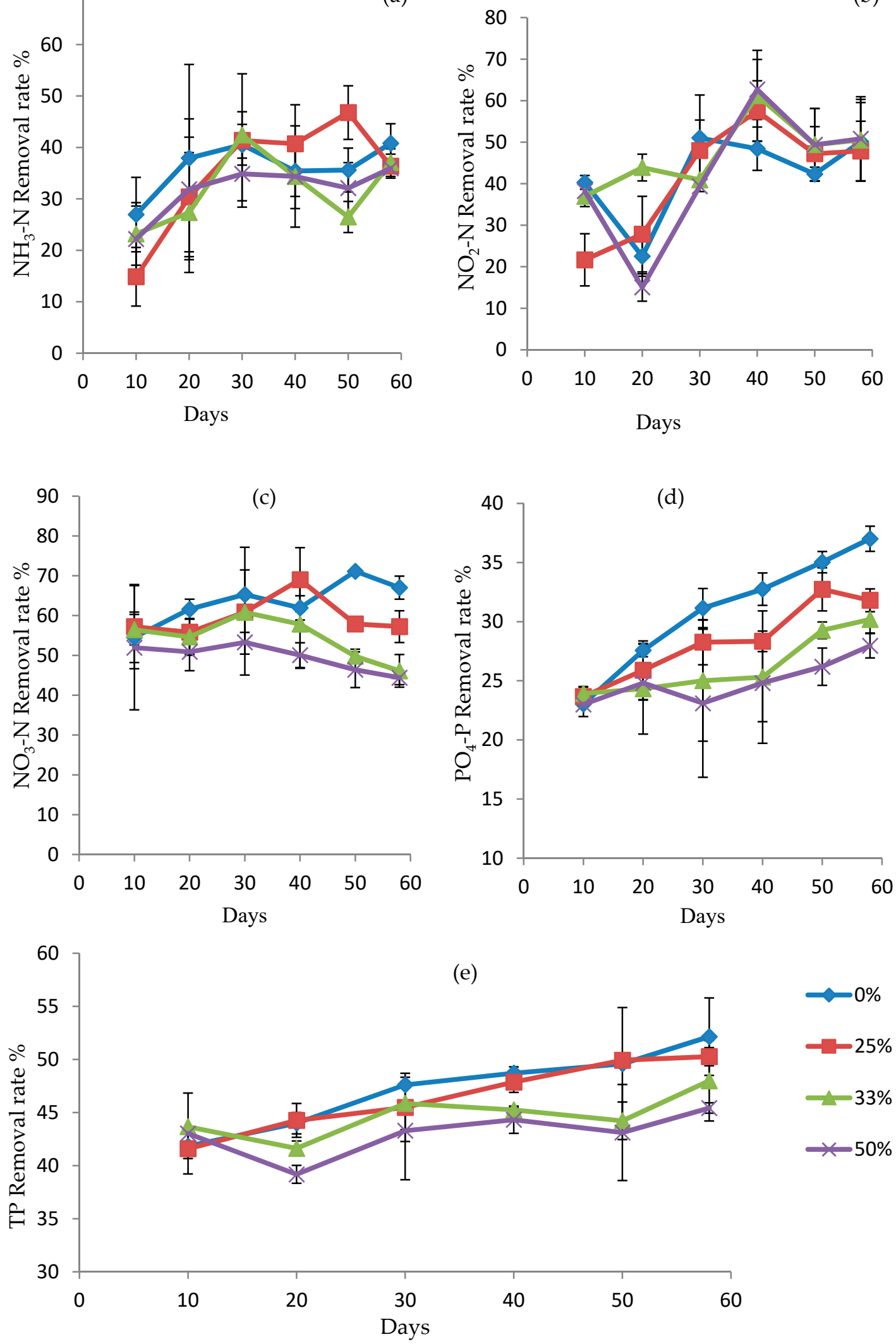

Figure 3. Removal rates for (a) ammonia nitrogen; (b) nitrite nitrogen; (c) nitrate nitrogen; (d) orthophosphate; and (e) total phosphorus in aquaponic systems under different plant harvesting regimes (data are the means of three replicates $(n=3)$, and error bars indicate the standard errors). 


\subsection{Concentrations of Nutrients Before and After Harvesting Plants}

The concentrations of $\mathrm{NO}_{3}-\mathrm{N}$ and $\mathrm{PO}_{4}-\mathrm{P}$ in the outlet of the bed units increased after two days of harvesting compared to the levels before two days of harvesting (Figure $4 b, c$ ), while the concentration of $\mathrm{NH}_{3}-\mathrm{N}$ started to increase after two days of the second harvesting (Figure $4 \mathrm{a}$ ).

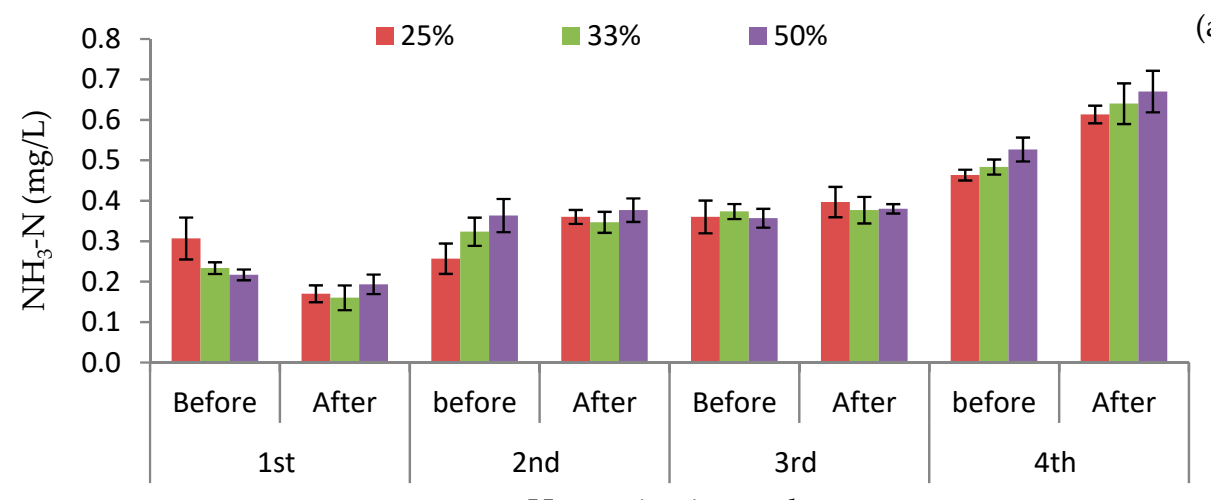

(a)

Harvesting intervals

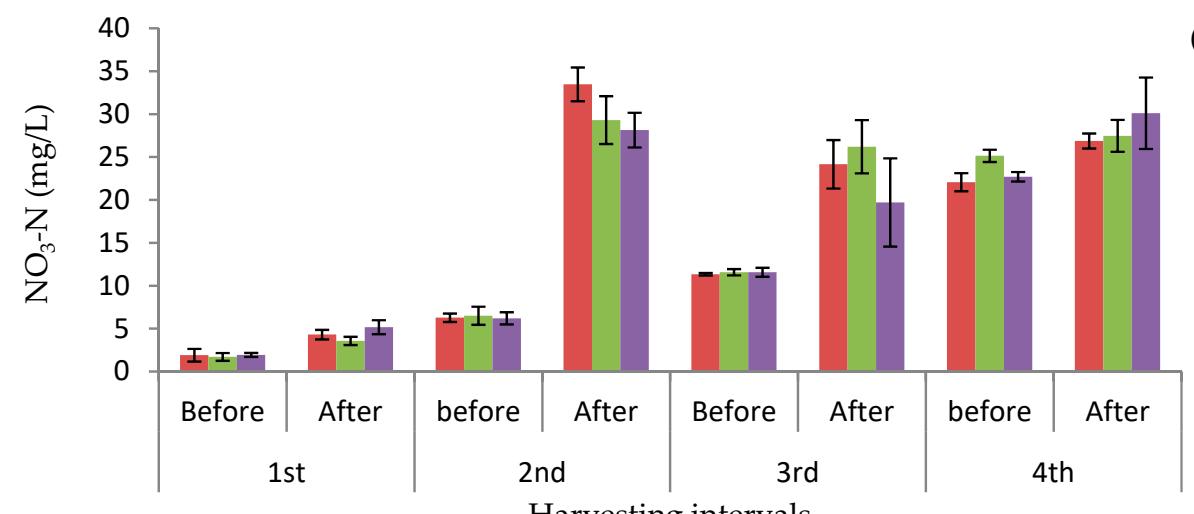

(b)

Harvesting intervals

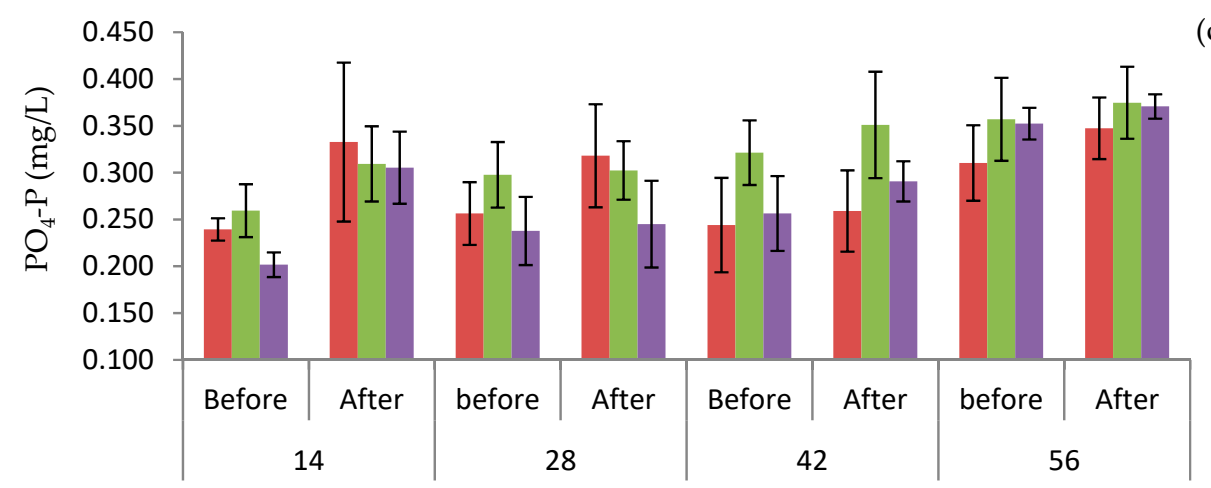

(c)

Harvesting intervals

Figure 4. Concentrations of (a) ammonia nitrogen; (b) nitrate nitrogen, and (c) orthophosphate at the outlet of the hydroponic beds before and after two days of harvesting plants (data are the means of three replicates $(n=3)$, and error bars indicate the standard errors).

\subsection{Fish and Plant Growth Performance}

After the experimental period, the growth rate of the common carp increased in all the treatments. The mean biomass gain, SGR, individual weight gain and FCR of the fish did not differ significantly $(p>0.05)$ amongst any of the treatments (Table 3$)$. The survival rates were also similar $(p>0.05)$ in all treatments, and no mortality was recorded in any system (Table 3). 
Table 3. Growth performance of Cyprinus carpio reared for 58 days in integrated recirculating aquaponic systems under different plant harvesting regimes.

\begin{tabular}{ccccc}
\hline \multirow{2}{*}{ Growth Parameters } & \multicolumn{4}{c}{ Harvested Biomass } \\
\cline { 2 - 5 } & $\mathbf{0 \%}$ & $\mathbf{2 5 \%}$ & $\mathbf{3 3 \%}$ & $\mathbf{5 0 \%}$ \\
\hline Initial fish weight (g/fish) & $33.71 \pm 0.10^{\mathrm{a}}$ & $33.75 \pm 0.08^{\mathrm{a}}$ & $33.64 \pm 0.04^{\mathrm{a}}$ & $33.55 \pm 0.99^{\mathrm{a}}$ \\
Final fish weight (g/fish) & $60.20 \pm 0.83^{\mathrm{a}}$ & $60.37 \pm 1.42^{\mathrm{a}}$ & $61.35 \pm 1.68^{\mathrm{a}}$ & $60.63 \pm 1.13^{\mathrm{a}}$ \\
Fish weight gain (g/fish/58 days) & $26.49 \pm 0.73^{\mathrm{a}}$ & $26.62 \pm 1.39^{\mathrm{a}}$ & $27.70 \pm 1.71^{\mathrm{a}}$ & $27.07 \pm 1.03^{\mathrm{a}}$ \\
Specific growth rate (\%/day) & $1.00 \pm 0.02^{\mathrm{a}}$ & $1.00 \pm 0.04^{\mathrm{a}}$ & $1.03 \pm 0.05^{\mathrm{a}}$ & $1.02 \pm 0.03^{\mathrm{a}}$ \\
Feed consumption (g/fish/day) & $0.67 \pm 0.00^{\mathrm{a}}$ & $0.67 \pm 0.00^{\mathrm{a}}$ & $0.67 \pm 0.00^{\mathrm{a}}$ & $0.67 \pm 0.00^{\mathrm{a}}$ \\
Fish weight gain (g/fish/day) & $0.46 \pm 0.01^{\mathrm{a}}$ & $0.46 \pm 0.03^{\mathrm{a}}$ & $0.48 \pm 0.03^{\mathrm{a}}$ & $0.47 \pm 0.02^{\mathrm{a}}$ \\
Feed conversion ratio & $1.46 \pm 0.04^{\mathrm{a}}$ & $1.46 \pm 0.07^{\mathrm{a}}$ & $1.40 \pm 0.08^{\mathrm{a}}$ & $1.43 \pm 0.06^{\mathrm{a}}$ \\
Survival (\%) & $100 \pm 0.00^{\mathrm{a}}$ & $100 \pm 0.00^{\mathrm{a}}$ & $100 \pm 0.00^{\mathrm{a}}$ & $100 \pm 0.00^{\mathrm{a}}$ \\
\hline
\end{tabular}

Values (means $\pm \mathrm{SE}$ ) in the same row with the same superscript letters are not significantly different (Duncan test; $p<0.05)$; data are the means of three replicates $(n=3)$.

The mean biomass gain and specific growth rates of the plants (SGRP) in the $0 \%$ systems were significantly higher $(p<0.05)$ than the values for the $33 \%$ and $50 \%$ harvested systems (Table 4 ). However, the mean biomass gain and SGRP of the $25 \%$ system were similar to the values for the unharvested and 33\% harvested systems (Table 4). The amount of harvested plants for the treatments increased during the harvesting times, except for the decrease in the $50 \%$ harvested system at the third and fourth harvestings (Figure 5a).

Table 4. Growth performance of Nasturtium officinale in integrated recirculating aquaponic systems under different harvesting regimes.

\begin{tabular}{|c|c|c|c|c|}
\hline \multirow{2}{*}{ Growth Parameters } & \multicolumn{4}{|c|}{ Harvested Biomass } \\
\hline & $0 \%$ & $25 \%$ & $33 \%$ & $50 \%$ \\
\hline Stocking biomass (g) & $240 \pm 0.00^{a}$ & $240 \pm 0.00^{a}$ & $240 \pm 0.00^{\mathrm{a}}$ & $240 \pm 0.00^{a}$ \\
\hline Biomass gain $(\mathrm{g})$ & $2340.0 \pm 180.0^{\mathrm{a}}$ & $1870.14 \pm 8.36^{\mathrm{ab}}$ & $1625.97 \pm 71.67^{b c}$ & $1316.90 \pm 187.95^{c}$ \\
\hline Specific growth rate of the plants (\%/day) & $4.090 \pm 0.120^{\mathrm{a}}$ & $3.745 \pm 0.005^{\mathrm{ab}}$ & $3.535 \pm 0.065^{b c}$ & $3.210 \pm 0.210^{c}$ \\
\hline
\end{tabular}

Values (means \pm SE) in the same row with different superscript letters $(a, b \ldots)$ are significantly different (Duncan test; $p<0.05)$; data are the means of three replicates $(n=3)$.

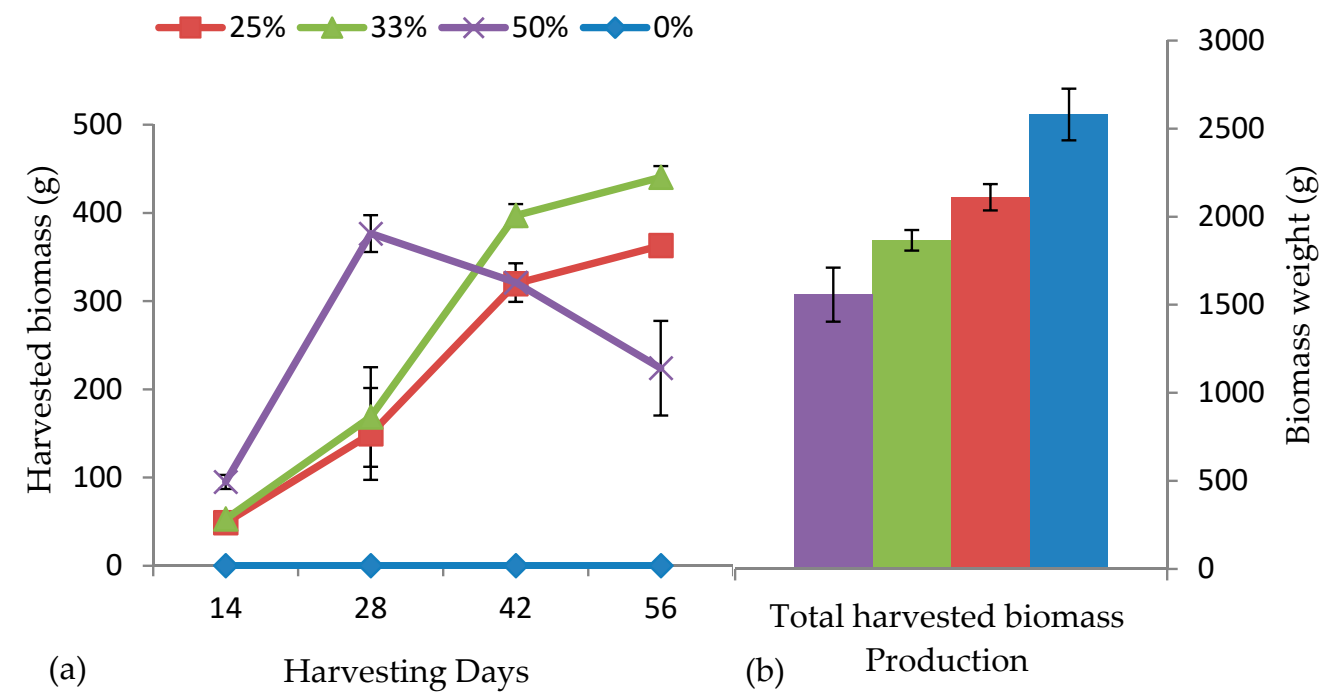

Figure 5. Harvested biomass of Nasturtium officinale in aquaponic systems under different harvesting regimes. (a) Amount of harvested plants on the 14th-56th days of the trial; (b) Total harvested biomass production in each treatment (data are the means of three replicates $(n=3)$, and error bars indicate the standard errors). 


\section{Discussion}

The aquaponic systems designed with watercress plants (N. officinale) in this study were efficient in removing nutrients because the plants take up the waste generated by the fish. The growth rate of the watercress increased exponentially in all treatments. However, our results showed that an increase in the harvested biomass of plants negatively affected the final biomass production (Table 4). Information relating to the influence of harvesting biomass on the growth performance and nutrient removal efficiency of plants in aquaponic systems is very limited; however, a very recent study found harvesting can cause damage to the plant tissues and that the plants after harvesting would not have the ability to transport nutrients and nonstructural carbohydrates from the stems and leaves to the storage organs, which could support the growth of new buds [16]. Several studies with different plant species also found that repeated aboveground harvesting can slow down plant biomass development because harvesting does not allow sufficient opportunity for plants to absorb more nutrients for growth, consequently leading to very low biomass production compared to that in those not harvested $[10,11,20,21]$. In the present study, the amount of harvested plants in the 50\% harvested system decreased at the third and fourth harvestings (Figure 5a), suggesting that harvesting can affect nutrient storage in plant tissues. Harvesting can alter the storage of rhizome carbohydrates needed for early growth and stand strength, depending on the time of harvest and the type of biomass harvested [20]. Our results are in agreement with the results obtained by [10], who found that increasing harvesting frequency had a large effect on Myriophyllum spicatum cover, height, composition, and abundance. On the other hand, [13] found that harvesting plants improved shoot density and the biomass of plants in the system compared with those in the unharvested system, while [8] found that the aboveground biomass was nearly identical at one and two time harvests.

After harvesting plants, the concentrations of $\mathrm{NH}_{3}-\mathrm{N}, \mathrm{NO}_{3}-\mathrm{N}$, and $\mathrm{PO}_{4}-\mathrm{P}$ in the outlet of the bed units were higher compared to the levels before two days of harvesting (Figure $4 \mathrm{a}-\mathrm{c}$ ), and this was probably due to a temporary reduction in the nutrient removal capacity of the system. The purification in rearing systems could be mediated by different mechanisms such as nitrification, denitrification, microbial assimilation, sedimentation, and plant uptake [22]. Plant uptake is one of the pathways for nutrient removal. When the plants are harvested, the microenvironment of the plant rhizosphere will be affected, leading to a decrease in the uptake of nutrients [16]. This is the one reason why the concentrations in the effluents of the bed units temporarily increased after two days of harvesting plants, especially for $\mathrm{NO}_{3}-\mathrm{N}$ and $\mathrm{PO}_{4}-\mathrm{P}$ (Figure 4). Similarly, [16] reported that the concentrations of $\mathrm{NO}_{3}-\mathrm{N}$ and $\mathrm{NH}_{4}-\mathrm{N}$ in the effluents increased temporarily after harvesting plants, and the effect on $\mathrm{NO}_{3}-\mathrm{N}$ was greater than that on $\mathrm{NH}_{4}-\mathrm{N}$, demonstrating that the harvesting of plant shoots would reduce the root exudates of the plants.

In aquaponic systems, nutrient removal capacity is influenced by the growth stage of the plants, nutrient needs of the plants, and activity of nitrifying bacteria $[3,4,19]$. Our results indicated that increasing the aboveground harvested biomass of plants had no effects on the ammonia and nitrite nitrogen removal efficiencies (Table 2), and this could be due to the activity of the nitrifying bacteria in the systems. It is reported in [3] that nitrifying bacteria are responsible for the major removal of ammonia and nitrite nitrogen in media-based aquaponic systems. Therefore, the activity of the nitrifying bacteria can describe the ammonia and nitrite nitrogen removal trends by all treatments in the present study. The increasing trends with the treatments were possibly due to the boost in the number of nitrifying bacteria in response to the rise in ambient ammonia concentrations as a consequence of the increasing fish biomass. At the early stage of the trial, there were not enough nitrifying bacteria to perform the nitrification process efficiently $[4,23,24]$. Similar findings were reported by [13], who found that the $\mathrm{NH}_{3}-\mathrm{N}$ and $\mathrm{NO}_{2}-\mathrm{N}$ removal efficiencies were comparable between the harvested and unharvested wetlands, and both wetlands in the second year showed higher nutrient removal than in the first year. On the other hand, [10] found that harvesting two times per growing season removed the highest amount of nitrogen from the system compared with the five times harvesting system. The results of another study revealed that harvesting during winter decreased $\mathrm{NH}_{4}-\mathrm{N}$ removal [12], 
while the results obtained by [9] revealed that the harvesting of shoots during summer could improve ammonia nitrogen removal.

Nitrates in aquaponic systems are taken up by plants as the main nitrogen source, and higher plant biomass translates to a higher plant uptake rate, resulting in a higher nitrate removal efficiency $[3,25]$. In the current study, the unharvested treatment had the highest plant biomass production (Figure $5 b$ ), resulting in the highest $\mathrm{NO}_{3}-\mathrm{N}$ removal efficiencies, which tended to increase as the plant biomass increased over time (Figure 3c). By contrast, the decreasing trends at the later stage of the experiment with the other treatments could be related to differences in the growth performance of plants, cover, and abundance of plants in the bed unit after harvesting. It was concluded in [10] that an increase in harvesting frequency negatively affected macrophyte cover, height, abundance, and biomass production, as well as total nutrient removal from the system. They found that an increase in the harvesting of plants up to five times removed a lower amount of nutrients from the system compared to the system of harvesting two times per growing season. Furthermore, it should be mentioned that an increase in the dissolved oxygen in the water to more than $4 \mathrm{mg} / \mathrm{L}$ can inhibit the denitrification process [13]. In our study, the dissolved oxygen in the hydroponic beds of all the treatments never dropped below $7.73 \mathrm{mg} / \mathrm{L}$, and this may provide further evidence that nitrates are directly taken up by plants as a nitrogen source and are incorporated into the plant biomass [26].

The removal of phosphorus can be mediated through plant uptake and the mechanism of sedimentation [27]. In [28], it is reported that over half of the phosphorus inputs are bound in the soils of the pond bottom in a relatively insoluble form. In the present study, the artificial feed was the only source of phosphorus, and a large part of it was removed by the removal of uneaten food and fish faeces, which resulted in a large portion of soluble phosphorus and suspended particles in the water column. Our results indicated an inverse relationship between the harvested biomass of plants and the $\mathrm{PO}_{4}-\mathrm{P}$ and TP removal capacities (Table 2). This was primarily due to the smaller plant biomass production in the systems $(0 \%>25 \%>33 \%>50 \%)$, as a result of the slow recovery of the plants and regrowth of biomass after harvesting (Figure 5a,b). The lower $\mathrm{PO}_{4}-\mathrm{P}$ and TP removal rates for all treatments at the beginning of the experiment could be attributed to the lower nutrient needs for the plants as a consequence of the smaller biomass of the plants (Figure 3d,e). In [29], it is reported that young plants have low nutrient requirements, which increase during the vegetative growth. Our findings were comparable to the findings reported by [11], who found the productivity of macrophytes to be affected significantly by harvesting, and this resulted in lower phosphorus removal compared to that in systems that were not harvested. It is also reported in [10] that harvesting two times per growing season removed the highest amount of phosphorus from the system compared with the five times harvesting system.

In the present study, all the water quality parameters in the fish tanks of the systems remained within the tolerance range for common carp growth and survival $[30,31]$. This was due to the effects of the nitrification process and plant uptake. The maximum value of $\mathrm{NH}_{3}(0.017 \mathrm{mg} / \mathrm{L})$ at the beginning of the experiment (Figure 2b) was lower than the concentrations reported by [32], who concluded that the common carp has three different concentration levels of $\mathrm{NH}_{3}$ : a favourable concentration $(0.0286 \mathrm{mg} / \mathrm{L})$, growth-inhibiting concentration $(0.034 \mathrm{mg} / \mathrm{L})$, and lethal concentration $(0.043 \mathrm{mg} / \mathrm{L})$. The maximum $\mathrm{NO}_{2}-\mathrm{N}$ concentration of $0.58 \mathrm{mg} / \mathrm{L}$ in the current study was much lower than the values reported by [33], who concluded that the common carp has three different concentration levels of nitrite: the lethal concentration $(88 \mathrm{mg} / \mathrm{L})$, that of lowest effect $(28 \mathrm{mg} / \mathrm{L})$, and that of no observed effect $(7 \mathrm{mg} / \mathrm{L})$. Furthermore, the maximum observed $\mathrm{NO}_{3}-\mathrm{N}$ concentration $(33.2 \mathrm{mg} / \mathrm{L})$ was much lower than lethal values of $865 \mathrm{mg} / \mathrm{L}$ reported by [34] for the common carp. Phosphate has no toxic effects on aquatic organisms $[35,36]$. However, [37] recommended that the orthophosphate concentration should be less than $15 \mathrm{mg} / \mathrm{L}$ in a closed recirculating system. In the present study, the levels of ammonia nitrogen, nitrite nitrogen, and nitrate nitrogen (Table 1) were within the acceptable levels for recirculating aquaculture systems [31] and aquaponic systems [38]. These concentrations were in agreement with 
the ranges of water quality variables achieved by [38] during the staggered culture of basil production in aquaponics.

Our results also revealed that an increase in the aboveground harvested biomass of plants did not affect the common carp growth and survival in aquaponic systems. The growth and survival of fish are influenced by water quality parameters in the culture system $[3,4,24,39,40]$. Thus, the similar growth performance between the fish in all the treatments was probably due to the equivalent water quality parameters during the study period, particularly the ammonia and nitrite concentrations. The SGRs of common carp in the present study, ranging from $1.00 \%$ to $1.03 \%$, were higher than the $0.39 \%$ reported by [23] and the $0.79 \%$ obtained by [41] for the common carp in different media-based aquaponic systems. Our results also were higher than the $0.841 \%$ and the $0.83 \%$ obtained by $[42,43]$ for koi carp (Cyprinus carpio var. koi) fed with $2 \%$ body weight in aquaponic systems. However, the SGRs of the fish were lower than those $(5.41 \%-5.50 \%)$ achieved by [44,45] for common carp reared in aquaponic systems. The lower SGRs may be related to the different temperature $\left(14.14{ }^{\circ} \mathrm{C}\right)$, feeding rates $(2 \%)$, and stocking density of the fish $\left(2.02 \mathrm{~kg} / \mathrm{m}^{3}\right)$ used in this study compared to those used by $[44,45]$ $\left(25.78^{\circ} \mathrm{C}, 5 \%\right.$ body weight and $0.090 \mathrm{~kg} / \mathrm{m}^{3}$, respectively).

\section{Conclusions}

This study aimed to evaluate the effects of harvesting plants on the nutrient removal capacity and growth of watercress in an aquaponic system. The findings of this paper reveal that increasing the biweekly harvested biomass of plants had negative effects on the growth performance of watercress in aquaponic systems, while it had no effects on the growth of common carp. The $0 \%$ and $25 \%$ systems were recorded to have the highest plant biomass production. In this study, watercress plants were efficient in removing nutrients generated by fish in aquaponic systems. However, increasing the harvested biomass of the plants had negative effects on the $\mathrm{NO}_{3}-\mathrm{N}$ and $\mathrm{PO}_{4}-\mathrm{P}$ removal efficiencies, while it had no effects on the $\mathrm{NH}_{3}-\mathrm{N}$ and $\mathrm{NO}_{2}-\mathrm{N}$ removal efficiencies. In the current study, the $0 \%$ and $25 \%$ systems were recorded to have the highest $\mathrm{NO}_{3}-\mathrm{N}$ and $\mathrm{PO}_{4}-\mathrm{P}$ removal efficiencies. The present study suggests that a biweekly harvesting of less than $25 \%$ of the growing area of watercress is recommended for improving nutrient removal efficiency and sustaining the growth of both fish and plants in aquaponic systems.

Author Contributions: Conceptualization, T.I. and M.B.; methodology, T.I., M.F., J.L., M.B. and P.B.; investigation, T.I., M.F., J.L. and P.B.; formal analysis, T.I., M.F., M.B. and P.B.; writing-original draft preparation, T.I.; writing-review and editing, T.I., M.F., M.B. and P.B.; supervision, M.B. and P.B.; project administration, M.B. and P.B.; funding acquisition, M.B. and P.B. All authors have read and agreed to the published version of the manuscript.

Funding: This work was supported by Tempus Public Foundation/Stipendium Hungaricum scholarship program, and the National Research Development and Innovation Fund of Hungary, financed under the project 2018-1.3.1-VKE-2018-00012, as well as by the EFOP-3.6.3-VEKOP-16-2017-00008 and HOP-3COLL-1 (reference number: 1699279607) projects; which are co-financed by the European Union and the European Social Fund, and by the European Regional and Development Fund and the Government of Hungary within the project GINOP-2.3.2-15-2016-00025.

Acknowledgments: We appreciate the help and cooperation of colleagues at Aquaculture Laboratory of Debrecen University and Georgikon Fish Research Laboratory during this work. Special thanks to Máté Havasi and Gábor Beliczky for their administrative, and technical assistance.

Conflicts of Interest: The authors declare no conflict of interest.

Ethical Approval: All actions related to fish use were according to the standards of the Animal Ethics Committee of Debrecen University, issued by the Department of the Food chain security of Hajdú-Bihar County.

\section{References}

1. Rakocy, J.E.; Masser, M.P.; Losordo, T.M. Recirculating Aquaculture Tank Production Systems: Aquaponics-Integrating Fish and Plant Culture; Southern Regional Aquaculture Center: Stoneville, MS, USA, 2016; pp. 1-16. 
2. Love, D.C.; Fry, J.P.; Li, X.; Hill, E.S.; Genello, L.; Semmens, K.; Thompson, R.E. Commercial aquaponics production and profitability: Findings from an international survey. Aquaculture 2015, 435, 67-74. [CrossRef]

3. Wongkiew, S.; Hu, Z.; Chandran, K.; Lee, J.W.; Khanal, S.K. Nitrogen transformations in aquaponic systems: A review. Aquac. Eng. 2017, 76, 9-19. [CrossRef]

4. Estim, A.; Saufie, S.; Mustafa, S. Water quality remediation using aquaponics sub-systems as biological and mechanical filters in aquaculture. J. Water Process. Eng. 2019, 30, 100566. [CrossRef]

5. Nhan, H.T.; Tai, N.T.; Liem, P.T.; Ut, V.N.; Ako, H. Effects of different stocking densities on growth performance of Asian swamp eel Monopterus albus, water quality and plant growth of watercress Nasturtium officinale in an aquaponic recirculating system. Aquaculture 2019, 503, 96-104. [CrossRef]

6. Smith, E.N. Watercress (Nasturtium officinale) Production Utilizing Brook Trout (Salvelinus fontinalis) Flow-Through Aquaculture Effluent. Master's Thesis, West Virginia University, Morgantown, WV, USA, 2007.

7. Woynarovich, A.; Bueno, P.B.; Altan, Ö.; Jeney, Z.; Reantaso, M.; Xinhua, Y.; Van Anrooy, R. Better Management Practices for Carp Production in Central and Eastern Europe, the Caucasus and Central Asia; FAO, Fisheries and Aquaculture Technical Paper: Ankara, Turkey, 2011; p. 153.

8. Vymazal, J.; Kröpfelová, L.; Švehla, J.; Štíchová, J. Can multiple harvest of aboveground biomass enhance removal of trace elements in constructed wetlands receiving municipal sewage? Ecol. Eng. 2010, 36, 939-945. [CrossRef]

9. Yang, Z.; Wang, Q.; Zhang, J.; Xie, H.; Feng, S. Effect of plant harvesting on the performance of constructed wetlands during summer. Water 2016, 8, 24. [CrossRef]

10. Verhofstad, M.J.J.M.; Poelen, M.V.; Van Kempen, M.M.L.; Bakker, E.S.; Smolders, A.J.P. Finding the harvesting frequency to maximize nutrient removal in a constructed wetland dominated by submerged aquatic plants. Ecol. Eng. 2017, 106, 423-430. [CrossRef]

11. Kim, S.Y.; Geary, P.M. The impact of biomass harvesting on phosphorus uptake by wetland plants. Water Sci. Technol. 2001, 44, 61-67. [CrossRef]

12. Wang, Q.; Xie, H.; Zhang, J.; Liang, S.; Ngo, H.H.; Guo, W.; Liu, C.; Zhao, C.; Li, H. Effect of plant harvesting on the performance of constructed wetlands during winter: Radial oxygen loss and microbial characteristics. Environ. Sci. Pollut. Res. 2014, 22, 7476-7484. [CrossRef]

13. Zheng, Y.; Wang, X.C.; Ge, Y.; Dzakpasu, M.; Zhao, Y.; Xiong, J. Effects of annual harvesting on plants growth and nutrients removal in surface-flow constructed wetlands in northwestern China. Ecol. Eng. 2015, 83, 268-275. [CrossRef]

14. Álvarez, J.A.; Bécares, E. The effect of vegetation harvest on the operation of a surface flow constructed wetland. Water SA 2008, 34, 645-650. [CrossRef]

15. Zheng, Y.; Dzakpasu, M.; Wang, X.; Zhang, L.; Ngo, H.H.; Guo, W.; Zhao, Y. Molecular characterization of long-term impacts of macrophytes harvest management in constructed wetlands. Bioresour. Technol. 2018, 268, 514-522. [CrossRef] [PubMed]

16. Sun, S.; Gao, L.; He, S.; Huang, J.; Zhou, W. Nitrogen removal in response to plants harvesting in two kinds of enhanced hydroponic root mats treating secondary effluent. Sci. Total Environ. 2019, 670, 200-209. [CrossRef] [PubMed]

17. Bartodziej, W.M.; Blood, S.L.; Pilgrim, K. Aquatic plant harvesting: An economical phosphorus removal tool in an urban shallow lake. J. Aquat. Plant Manag. 2017, 55, 26-34.

18. HACH. DR/3900 Spectrophotometer Procedure Manual; HACH Company: Loveland, CO, USA, 2019.

19. Gichana, Z.; Meulenbroek, P.; Ogello, E.; Drexler, S.; Zollitsch, W.; Liti, D.; Akoll, P.; Waidbacher, H. Growth and Nutrient Removal Efficiency of Sweet Wormwood (Artemisia annua) in a Recirculating Aquaculture System for Nile Tilapia (Oreochromis niloticus). Water 2019, 11, 923. [CrossRef]

20. Jinadasa, K.; Tanaka, N.; Sasikala, S.; Werellagama, D.; Mowjood, M.; Ng, W. Impact of harvesting on constructed wetlands performance-A comparison between Scirpus grossus and Typha angustifolia. J. Environ. Sci. Health A 2008, 43, 664-671. [CrossRef]

21. Jeke, N.N.; Zvomuya, F.; Cicek, N.; Ross, L.; Badiou, P. Nitrogen and phosphorus phytoextraction by Cattail (Typha spp.) during wetland-based phytoremediation of an end-of-life municipal lagoon. J. Environ. Qual. 2019, 48, 24-31. [CrossRef]

22. Saeed, T.; Sun, G. A review on nitrogen and organics removal mechanisms in subsurface flow constructed wetlands: Dependency on environmental parameters, operating conditions and supporting media. J. Environ. Manag. 2012, 112, 429-448. [CrossRef] 
23. Knaus, U.; Palm, H.W. Effects of the fish species choice on vegetables in aquaponics under spring-summer conditions in northern Germany (Mecklenburg Western Pomerania). Aquaculture 2017, 473, 62-73. [CrossRef]

24. Irhayyim, T.; Fotedar, R. Effects of fish size and biofiltration techniques on water quality and nitrogen removal efficiency in recirculating aquaculture systems. AACL Bioflux 2019, 12, 1606-1616.

25. Hu, Z.; Lee, J.W.; Chandran, K.; Kim, S.; Brotto, A.C.; Khanal, S.K. Effect of plant species on nitrogen recovery in aquaponics. Bioresour. Technol. 2015, 188, 92-98. [CrossRef] [PubMed]

26. Fang, Y.Y.; Babourina, O.; Rengel, Z.; Yang, X.E.; Pu, P.M. Ammonium and nitrate uptake by the floating plant Landoltia punctata. Ann. Bot. 2007, 99, 365-370. [CrossRef] [PubMed]

27. Bunce, J.T.; Ndam, E.; Ofiteru, I.D.; Moore, A.; Graham, D.W. A review of phosphorus removal technologies and their applicability to small-scale domestic wastewater treatment systems. Front. Environ. Sci. 2018, 6, 1-15. [CrossRef]

28. Midlen, A.; Redding, T. Environmental Management for Aquaculture; Chapman and Hall: London, UK, 1998.

29. Jones, C.; Olson-rutz, K.; Dinkins, C. Nutrient Uptake Timing by Crops, to Assist with Fertilizing Decisions; Montana State University: Bozeman, MT, USA, 2015; p. 8.

30. Horváth, L.; Tamas, G.Y.; Seagrave, C. Carp and Pond Fish Culture, 2nd ed.; Blackwell science Ltd.: Oxford, UK, 2002.

31. Timmons, M.B.; Ebeling, J.M.; Wheaton, F.W.; Summerfelt, S.T.; Vinci, B.J. Recirculating Aquaculture Systems, 2nd ed.; Cayuga Aqua Ventures: Ithaca, NY, USA, 2002.

32. Biswas, J.K.; Sarkar, D.; Chakraborty, P.; Bhakta, J.N.; Jana, B.B. Density dependent ambient ammonium as the key factor for optimization of stocking density of common carp in small holding tanks. Aquaculture 2006, 261, 952-959. [CrossRef]

33. Kroupova, H.; Prokes, M.; Macova, S.; Penaz, M.; Barus, V.; Novotny, L.; Machova, J. Effect of nitrite on early-life stages of common carp (Cyprinus carpio L). Environ. Toxicol. Chem. 2010, 29, 535-540. [CrossRef]

34. Iqbal, F.; Qureshi, I.Z.; Ali, M. Histopathological changes in kidney of common carp, Cyprinus carpio, following nitrate exposure. J. Res. Sci. 2004, 15, 411-418.

35. Kim, E.; Yoo, S.; Ro, H.Y.; Han, H.J.; Baek, Y.W.; Eom, I.C.; Kim, H.M.; Kim, P.; Choi, K. Aquatic toxicity assessment of phosphate compounds. Environ. Health Toxicol. 2013, 28, 1-7. [CrossRef]

36. Simplício, N.; Muniz, D.; Rocha, F.; Martins, D.; Dias, Z.; Farias, B.; Oliveira-Filho, E.C. Comparative analysis between ecotoxicity of nitrogen-, phosphorus-, and potassium-based fertilizers and their active ingredients. Toxics 2017, 5, 2. [CrossRef]

37. Suzuki, Y.; Maruyama, T.; Numata, H.; Sato, H.; Asakawa, M. Performance of a closed recirculating system with foam separation, nitrification and denitrification units for intensive culture of eel: Towards zero emission. Aquac. Eng. 2003, 29, 165-182. [CrossRef]

38. Rakocy, J.E.; Bailey, D.S.; Shultz, R.C.; Thoman, E.S. Update on tilapia and vegetable production in the UVI aquaponic system. In New Dimensions on Farmed Tilapia, Proceedings of the Sixth International Symposium on Tilapia in Aquaculture, Manila, Philippines, September 12-16; Remedios, B., Graham, M., Kevin, F., Eds.; Center Roxas Boulevard: Manila, Philippines, 2004.

39. Colt, J. Water quality requirements for reuse systems. Aquac. Eng. 2006, 34, 143-156. [CrossRef]

40. Ardiansyah, A.; Fotedar, R. Water quality, growth and stress responses of juvenile barramundi (Lates calcarifer Bloch), reared at four different densities in integrated recirculating aquaculture systems. Aquaculture 2016, 458, 113-120. [CrossRef]

41. Maucieri, C.; Nicoletto, C.; Zanin, G.; Birolo, M.; Trocino, A.; Sambo, P.; Borin, M.; Xiccato, G. Effect of stocking density of fish on water quality and growth performance of European Carp and leafy vegetables in a low-tech aquaponic system. PLoS ONE 2019, 14. [CrossRef] [PubMed]

42. Hussain, T.; Verma, A.K.; Tiwari, V.K.; Prakash, C.; Rathore, G.; Shete, A.P.; Nuwansi, K.K.T. Optimizing koi carp, Cyprinus carpio var. koi (Linnaeus, 1758), stocking density and nutrient recycling with spinach in an aquaponic system. J. World Aquac. Soc. 2014, 45, 652-661. [CrossRef]

43. Hussain, T.; Verma, A.K.; Tiwari, V.K.; Prakash, C.; Rathore, G.; Shete, A.P.; Saharan, N. Effect of water flow rates on growth of Cyprinus carpio var. koi (Cyprinus carpio L., 1758) and spinach plant in aquaponic system. Aquac. Int. 2015, 23, 369-384. [CrossRef] 
44. Shete, A.P.; Verma, A.K.; Chadha, N.K.; Prakash, C.; Peter, R.M.; Ahmad, I.; Nuwansi, K.K.T. Optimization of hydraulic loading rate in aquaponic system with Common carp (Cyprinus carpio) and Mint (Mentha arvensis). Aquac. Eng. 2016, 72, 53-57. [CrossRef]

45. Shete, A.P.; Verma, A.K.; Chadha, N.K.; Prakash, C.; Chandrakant, M.H.; Nuwansi, K.K.T. Evaluation of different hydroponic media for mint (Mentha arvensis) with common carp (Cyprinus carpio) juveniles in an aquaponic system. Aquac. Int. 2017, 25, 1291-1301. [CrossRef]

(c)

(C) 2020 by the authors. Licensee MDPI, Basel, Switzerland. This article is an open access article distributed under the terms and conditions of the Creative Commons Attribution (CC BY) license (http://creativecommons.org/licenses/by/4.0/). 